\title{
THE ROLE OF GEOMORPHIC CONTROLS ON THE DEVELOPMENT OF DEFENSIVE NETWORKS ALONG THE WESTERN FRONT DURING THE GREAT WAR: CASE STUDY OF CHAMPAGNE AND ARGONNE (FRANCE)
}

\author{
P. Taborelli, A. Devos, S. Laratte (Université de Reims \\ Champagne-Ardenne) and J. Brenot (Éveha)
}

\begin{abstract}
The Great War was marked on the western front mainly by a war of position (for 40 out of the 51 months of the conflict) along the $750 \mathrm{~km}$ of the front area from Flanders to Alsace. The objective of this article is to understand the spatial organisation of defence networks in the eastern part of the Champagne region (Champagne sèche), the Vallage d'Aisne and in the Argonne region in 1918 by means of an analysis of geographical information system (GIS)-processed trench maps. This article presents a methodology, involving the transfer of fire trenches, communication trenches and vegetation, integrated into a geodatabase, and then cross-referenced with the digital terrain model (DTM). This comparison of three distinct regions with a chalky plateau (Champagne sèche), a wet plain (Vallage d'Aisne) and a sandy plateau covered with forests (Argonne), not only makes it possible to qualify the role of geographical conditions on the Great War but also to quantify the defence networks.
\end{abstract}

Key words: WW1, trench map, GIS, spatial analysis, Champagne sèche, Vallage d'Aisne, Argonne.

\section{Introduction}

During the recent Centenary of the Great War and in the last century, numerous publications, research reports and studies were published, mainly about historical and social aspects of the Champagne ${ }^{1}$ and Argonne regions ${ }^{2}$. Over the past twenty years, new multidisciplinary research has focused on the archaeology of the Great $\mathrm{War}^{3}$, bringing together historians, geographers, archaeologists and geo-archaeologists, with the innovative scientific support of archaeometry ${ }^{4}$. The spatial aspect, previously confined to the successive battles of the conflict ${ }^{5}$, makes the terrain the focal point, which constitutes not only a real experimental laboratory for researchers ${ }^{6}$ but also an excellent potential for cultural heritage ${ }^{7}$. 
The need for spatial and historical contextualisation of the studied sites raises the recurrent problem of the impact of geographical conditions on the spatial organisation of the front ${ }^{8}$, an approach facilitated by the geographical information systems (GIS). To understand the spatial approach of the front, numerous and diverse sources need to be assessed: the writings and illustrations of soldiers, the military instruction manuals, aerial photographs ${ }^{9}$ and the trench maps all provide spatial information. ${ }^{10}$ The study on which this article reports, aimed to understand the role of relief, geology and hydrography in structuring the front of the Great War based on three contiguous but geomorphologically different regions (Champagne sèche, Vallage d'Aisne or Wet Champagne, and Argonne). Indeed, the front is too often represented as a line of deep ternary organisation, structured in positions, and lines of fire trenches and communication trenches. ${ }^{11}$

\section{Geographical and historical background}

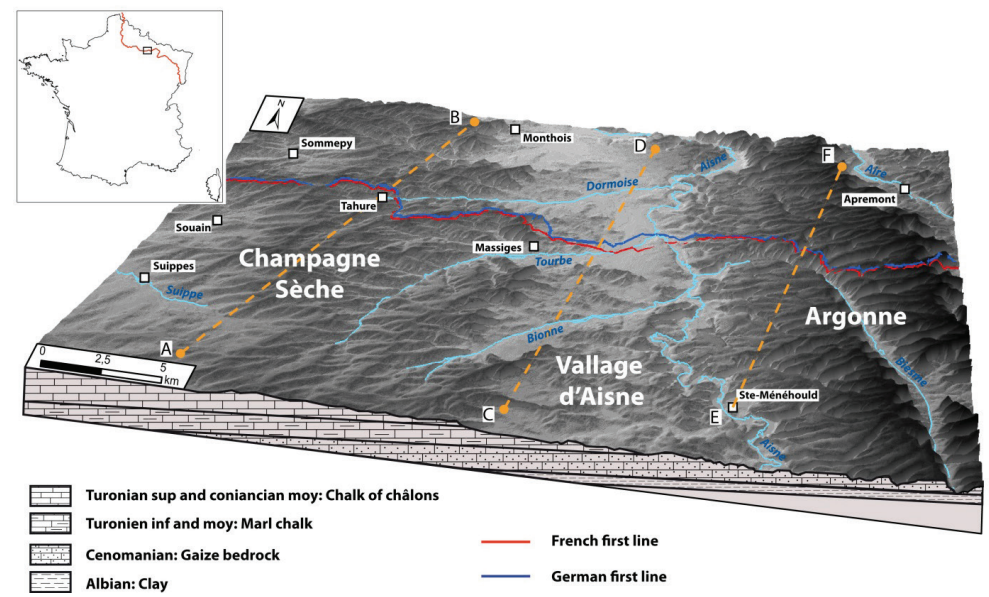

Figure 1: Location map of the studied area and World War 1 (WW1) front line in the Champagne plain and the Argonne regions (hills). Both underlying geology and present-day topography are shown.

The study area covers $45 \mathrm{~km}$ of the front line in France, between Reims and Verdun. It is part of three natural regions: Champagne sèche, Vallage d'Aisne and Argonne (Figure 1).

The chalky or pungent Champagne region, also called Champagne sèche, is the reverse western side of the Coast of Champagne in the Upper Cretaceous Chalk (Upper Turonian of the Campanian). The cuesta has a rugged topography owing to the anaclinal tributaries on the left bank of the Aisne (Bionne River, Dormoise River, Tourbe River, Muette River) and tributary valleys that are generally dry because they 
are periglacials. These 'ravines' separate promontories, spurs or salients or 'hills' whose shape evokes the fingers of a hand north of Massiges City (hence the name 'Hand of Massiges', Figure 2) or 'Viper's Head' further north that rises to $199 \mathrm{~m}$ at Têtu Hill. Each spur corresponds to a finger of the hand with from west to east, the false Thumb, the Thumb, the Index, the Medium and the Annular. If the spurs are fortified by several lines of trenches, the ravines under the fire remain poorly equipped in fire trenches and communication trenches. Their slopes are dug as underground galleries under the fingers of the Hand of Massiges. This site was the place of harsh fighting in September-October 1915 ( $2^{\text {nd }}$ Champagne offensive) for the takeover by the $2^{\text {nd }}$ French Army of the Hand of Massiges. The spurs of the Coast of Champagne provide many sites of major strategic interest, serving as points of support for the defence and observation devices for the adjustment of artillery fire. These spurs and the Hill of Champagne were covered with cultivated areas dominated by pine forests at the time.

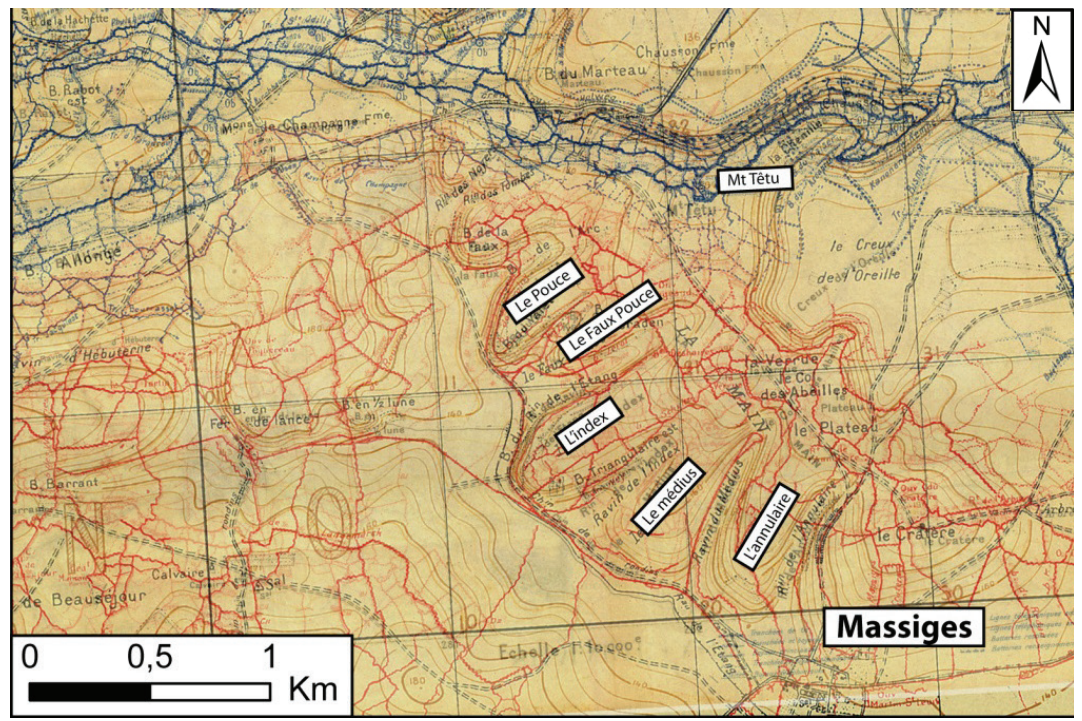

Figure 2: Section of trench map of Cernay-en-Dormois (chalky Champagne region) in 1918 (personal collection).

The wet Champagne region or Vallage d'Aisne constitutes the orthoclinal depression of the Coast of Champagne. To the east, in the soft formations of the lower Turonian (marly chalk), hydromorphic soils characterise this flat plain, drained by the Aisne River and its tributaries on the left bank (Bionne River, Tourbe River, Dormoise River). Without large forest massifs, it is cultivated, grazed and punctuated with isolated woods. This front stabilised in Champagne sèche and Vallage d'Aisne until the return of movement to the war in September 1918. 
The Argonne region forms the reverse of the Cenomanian (or Argonne) coast made comprising Albo-Cenomanian gaize, a porous, grey-green, siliceous sandstone, relatively soft and light (density between 1.4 and 1.54) resting on impermeable clays of the Albian (Gault clay). ${ }^{12}$ The Argonne region, is enclosed between the Aisne River to the west, and its tributary, the Aire River, to the east, which presents a southern course including numerous valleys and tributary ravines, named "barribans" by Léry in $1916::^{13}$

On all sides, in every direction, they are very narrow ravines, with steep sides. The locals call them "barribans". They constitute an insurmountable obstacle to anyone who wishes, to walk in the woods, outside the paths.

These ravines incise the surface by intersecting the gaize and the underlying clays. They drain numerous streams fed by source lines and barred by water bodies, whose humidity is sustained by heavy annual precipitations (up to $1200 \mathrm{~mm}$ in ChâtelChéhéry). This coast-oriented overall north-south forms a natural barrier or forest barrier ${ }^{14}$ with a command of about $100 \mathrm{~m}$ for an invader coming from the east. The forest cover, the lack of a wide communication channel and the segmentation of the coast by the ravines comprised a real brake on the progress of troops in this forest.

After advancing fast in August 1914 and retreating on high points, the German army entered the Argonne forest at the end of September 1914 to make the link between the front at Champagne and the Vauquois Hill before Verdun. The French army was already installed in the forest and resisted in front of the German advance, fixing the front in mid-October. Even though this front was secondary, the French army had to contain the enemy to avoid an overflow by the west of Verdun as well as to protect the railway line between Châlons-sur-Marne and Verdun. From the end of September 1914 to the end of July 1915, the German operations in Argonn, caused only a localised retreat of $1 \mathrm{~km}$ of the front in the wood of the Gruerie, HauteChevauchée and in the sector of the Fille Morte. This French retreat is visualised by the presence of mine craters in the Harazée sector, illustrating the former front line of the sector. During this position warfare, the mine warfare dominated, making the Argonne a true example of the underground war. It was not until the September and October 1918 offensives that the Argonne front was active again. The French army to the west on the chalky area and the American army to the east in the valley of the Aire River were advancing more rapidly than the two divisions engaged in the Argonne forest. The Germans performed numerous ambushes in the forest and the front then encountered a salient towards the south. About 150000 soldiers died on this $20 \mathrm{~km}$ of front during the four years of war.

\section{Data collection and methodology}

The trench maps are military maps representing the defence networks of the front during the Great War. Given the inadequacy of the ordnance survey map to the static and trench warfare ${ }^{15}$, the French Army Geographical Service created the Groupes des 
Canevas de Tir (GCTA) whose status was officially authorised in January $1915^{16}$. One of the missions of the GCTA was to provide maps of enemy defence networks and enemy artillery positions with a new planimetric grid, a new map projection (Lambert North War Area), a new levelling of altitudes, with three scales (1/20 000, 1/10 000 and 1/5 000) and two colours: red for the allied organisations and blue for the German organisations. ${ }^{17}$ The GCTA worked on the basis of the information gathered by aerial observation (oblique and azimuthal photographs), sound tracking sections (SRS), terrestrial observation sections (SROT), topographic sections of army corps and division, and questioning of enemy prisoners. The production of trench maps varied between 1914 and 1918, from 6000 to 4460000 copies. The German army would have produced 60 million. These are housed in the national, regional and departmental archives, but the majority are in the Defence Historical Service (Paris) and in private collections. They suffer of a great dispersion but have the advantage of concentrating a large amount of filtered and interpreted information by the GCTA ${ }^{18}$. The documents are richer in information than aerial photographs, which is why the present contribution proposes to use them to understand the spatial organisation of the front. They are also used and contextualised in their historical context, in the form of excerpts, in the Journal de Marche des Opérations (JMO) available online on the site of the French Ministry of Defense (Men's Memory).

The organisation of the front was studied before the Ludendorff offensives and the return of the movement warfare, using the six trench maps (Tahure, Cernay-enDormois, Argonne Forest, Somme-Suippe, Valmy and Sainte-Ménéhould). After high-definition digitisation, they were geo-referenced in a GIS using existing and current databases (Scan 25, DB Topo with a resolution of $25 \mathrm{~m}$ ). These 1/20 000 military maps present the entire defence network of each camp, red for the Allied Army and blue for the German Army (Figure 2). 


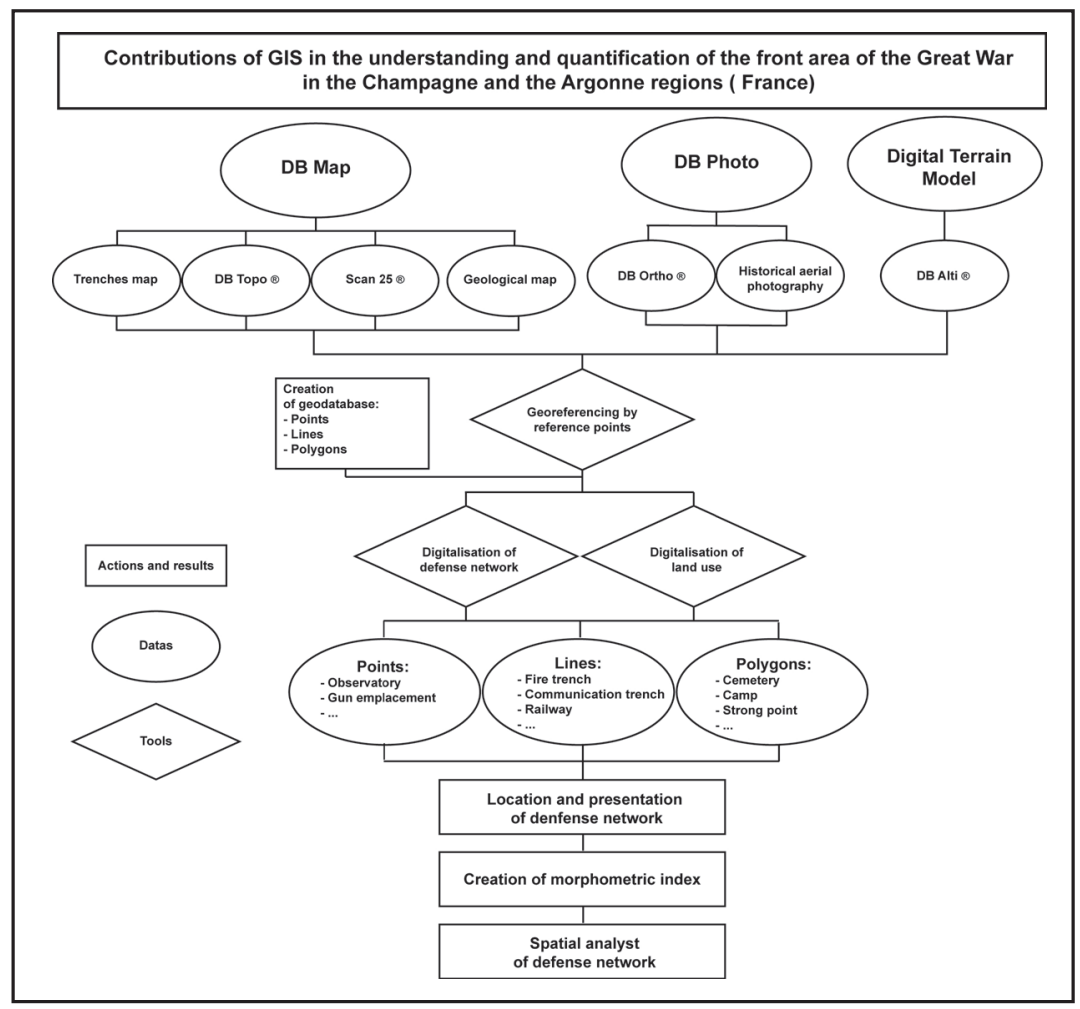

Figure 3: Organisation for work

Each entity could then be digitised using the GIS tool in three categories (Figure 3):

- point object: examples included observatory, artillery battery;

- object of line type: examples included fire trench, communication trench, railways; and

- object of type polygon: examples included strong point, cemetery, camps.

The built and forested areas were also digitised as a polygon to provide information on land use at the time. Additional details on the nature of the entity, its use and/or its toponym were incorporated into each object where such indications were available. Finally, to link defence networks and terrain, the database was crossed with the $25 \mathrm{~m}$ digital terrain model (DTM) (DB ALTI IGN). Morphometric indices were used in a spatial analysis of defence networks (minimum, maximum and average lengths, No Man's Land area, linear density, and number of craters). 


\begin{tabular}{|c|c|c|c|c|c|c|c|c|c|c|c|c|c|c|c|}
\hline పే & 营 & $\begin{array}{l}\infty \\
n \\
n\end{array}$ & $\begin{array}{l}n \\
i\end{array}$ & $\begin{array}{l}\text { I } \\
\infty \\
\sim\end{array}$ & $\hat{n}$ & శิ & $\bar{\sigma}$ & $r$ & $\begin{array}{l}0 \\
\vec{\lambda}\end{array}$ & $\begin{array}{l}\text { ते } \\
\text { ঠे }\end{array}$ & $\begin{array}{l}\infty \\
\infty \\
0 \\
i\end{array}$ & $\frac{\overrightarrow{\hat{N}}}{\hat{\Xi}}$ & $\begin{array}{l}n \\
\dot{f}\end{array}$ & $\stackrel{n}{m}$ & $\stackrel{\infty}{\sim}$ \\
\hline 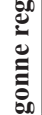 & 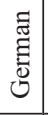 & 1 & 1 & 1 & 1 & 1 & 1 & $\sim$ & $\begin{array}{l}\infty \\
0 \\
0\end{array}$ & $\overrightarrow{\mathrm{n}}$ & $\begin{array}{l}\stackrel{\infty}{\mathbb{J}} \\
\text { त. }\end{array}$ & $\begin{array}{l}\hat{b} \\
\hat{n}\end{array}$ & $\stackrel{\infty}{\stackrel{\infty}{\sigma}}$ & \begin{tabular}{l}
$\stackrel{N}{ \pm}$ \\
\multirow{J}{*}{}
\end{tabular} & m \\
\hline$\overline{4}$ & 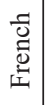 & 1 & 1 & 1 & 1 & 1 & 1 & $n$ & $\begin{array}{l}\infty \\
\pm \\
\pm\end{array}$ & $\begin{array}{l}\hat{8} \\
\stackrel{一}{2}\end{array}$ & $\begin{array}{l}0 \\
\text { ḋ } \\
\text { no }\end{array}$ & $\begin{array}{l}\infty \\
\dot{\delta}\end{array}$ & 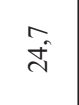 & $\stackrel{n}{2}$ & ষ \\
\hline 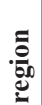 & 要 & $\stackrel{\infty}{\sim}$ & $\begin{array}{l}n \\
+\end{array}$ & $\begin{array}{l}\hat{\jmath} \\
\text { है }\end{array}$ & in & 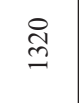 & $=$ & $\infty$ & $\vec{\AA}$ & 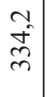 & $\stackrel{\tilde{N}}{\stackrel{\sim}{\sim}}$ & in & 犬े & $\vec{m}$ & $\mathbb{Z}$ \\
\hline 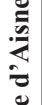 & 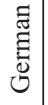 & 1 & 1 & 1 & 1 & 1 & 1 & $m$ & $\stackrel{\nabla_{n}}{\sim}$ & 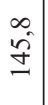 & $\begin{array}{l}0 \\
\dot{J}\end{array}$ & $\underset{a}{\stackrel{a}{d}}$ & $\hat{\infty}$ & $\stackrel{m}{2}$ & m \\
\hline 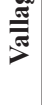 & 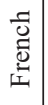 & 1 & 1 & 1 & 1 & 1 & 1 & $n$ & $\hat{\mathrm{a}}$ & $\begin{array}{c}2 \\
\infty \\
\infty \\
\infty\end{array}$ & $\begin{array}{l}\hat{\infty} \\
\stackrel{n}{n}\end{array}$ & $\begin{array}{l}\stackrel{0}{N} \\
\underset{n}{n}\end{array}$ & 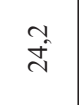 & $\stackrel{\infty}{=}$ & $\vec{\partial}$ \\
\hline 言 & 点 & $\stackrel{n}{\sim}$ & $\stackrel{\nabla_{1}}{m}$ & $\vec{\infty}$ & 6 & $\widetilde{\approx}$ & in & $\infty$ & $\begin{array}{l}\vec{d} \\
\vec{d}\end{array}$ & 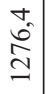 & $\begin{array}{l}\underset{\infty}{\Xi} \\
\underset{\Xi}{D}\end{array}$ & 竎 & $\begin{array}{l}\forall \\
\text { જे }\end{array}$ & $\hat{\sigma^{\circ}}$ & $\stackrel{0}{=}$ \\
\hline 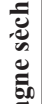 & 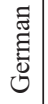 & 1 & 1 & 1 & 1 & 1 & 1 & $\nabla$ & $\overrightarrow{0}$ & $\begin{array}{c}m \\
\tilde{\delta} \\
\tilde{n}\end{array}$ & $\begin{array}{l}\vec{\infty} \\
\dot{0}\end{array}$ & $\frac{n}{\infty}$ & $\stackrel{\nabla}{\tilde{v}}$ & $\vec{\Xi}$ & ? \\
\hline $\begin{array}{l}\bar{E} \\
\bar{E} \\
\bar{E}\end{array}$ & 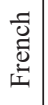 & 1 & 1 & 1 & 1 & 1 & 1 & $\nabla$ & $\begin{array}{l}\infty \\
\pm \\
\pm\end{array}$ & $\overrightarrow{\mathfrak{n}}$ & $\begin{array}{l}0 \\
i \\
\infty \\
\infty\end{array}$ & ్ֶరి & 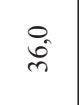 & भे & $n$ \\
\hline & 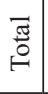 & $\vec{f}$ & $\begin{array}{l}\dot{\sigma}_{0} \\
\stackrel{0}{*}\end{array}$ & $\begin{array}{l}0 \\
\ddot{\theta} \\
\ddot{\theta}\end{array}$ & $\hat{n}$ & 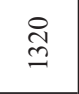 & $\underline{6}$ & 1 & 1 & $\begin{array}{l}\overrightarrow{0} \\
\stackrel{\sim}{\pi} \\
\vec{\lambda}\end{array}$ & 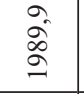 & $\begin{array}{l}n \\
\tilde{y} \\
\stackrel{r}{\sigma}\end{array}$ & $\stackrel{m}{i}$ & $\vec{f}$ & $\stackrel{\forall}{n}$ \\
\hline है & 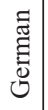 & 1 & 1 & 1 & 1 & I & 1 & I & 1 & $\begin{array}{l}\hat{\sigma} \\
\stackrel{0}{0}\end{array}$ & $\frac{0}{\hat{a}}$ & 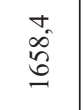 & $\hat{\vec{\lambda}}$ & $\stackrel{\nabla}{\sim}$ & $\hat{\delta}$ \\
\hline & $\begin{array}{l}\overrightarrow{0} \\
\overrightarrow{0} \\
\text { 离 }\end{array}$ & 1 & 1 & 1 & 1 & 1 & 1 & 1 & 1 & $\begin{array}{l}\tilde{1} \\
\tilde{n} \\
\tilde{=}\end{array}$ & $\begin{array}{l}\infty \\
\text { İ } \\
\text { ปે }\end{array}$ & $\begin{array}{l}\text { İ } \\
\text { d }\end{array}$ & बे & $\begin{array}{l}b_{0} \\
\text { î }\end{array}$ & $\begin{array}{l}b_{0} \\
\infty \\
i n\end{array}$ \\
\hline & 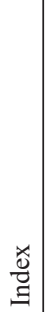 & 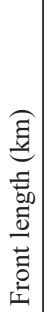 & 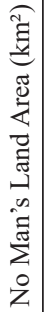 & 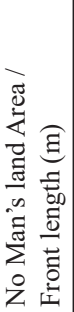 & 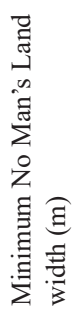 & 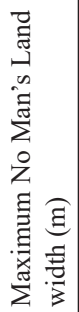 & 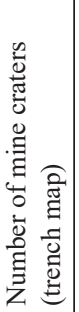 & 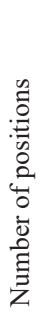 & 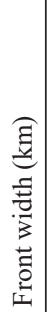 & 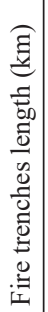 & 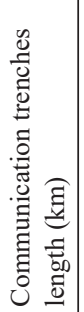 & 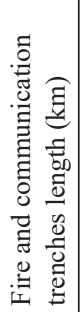 & 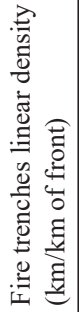 & 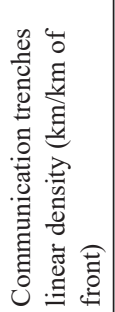 & 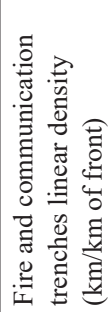 \\
\hline
\end{tabular}




\section{Results and discussion}

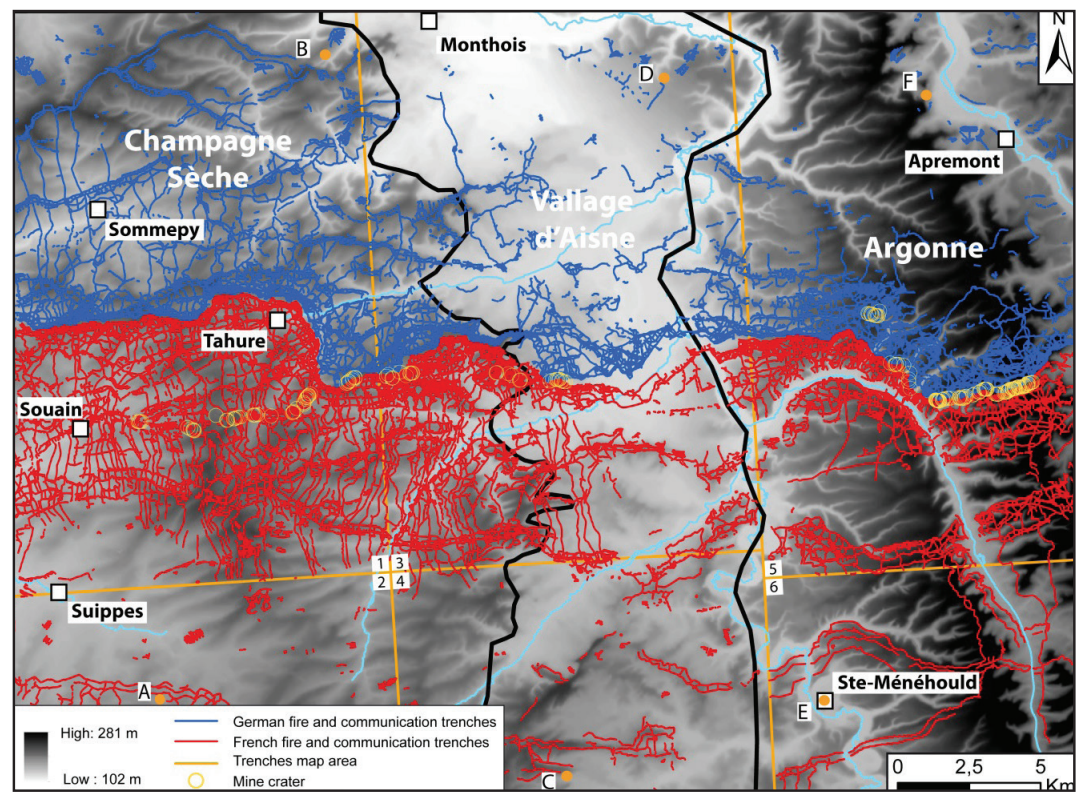

Figure 4: Map of defence network in Champagne sèche, Vallage d'Aisne and Argonne region (1918). Index to trench map: (1) Tahure, (2) Somme-Suippe, (3) Cernay-en-Dormois, (4) Valmy, (5) Forêt d'Argonne, and (6) Sainte-Ménéhould.

The front, represented as a line, was in reality an area of about 20 to $30 \mathrm{~km}$, structured and hierarchised in terms of position. A position was structured with at least four trenches. On this front of about $45 \mathrm{~km}$ (representing $6 \%$ of the western front), $4303 \mathrm{~km}$ of fire trenches and communication trenches were digitised, with a corresponding density of $95 \mathrm{~km}$ of fire trenches and communication trenches per kilometre of front. However, this number masks huge differences. While the Vallage d'Aisne and the Argonne regions had an average of 74 and $78 \mathrm{~km}$ of fire trenches and communication trenches per kilometre of front, the Champagne sèche region was densely fortified with $116 \mathrm{~km}$ (1.5 times that of the other two) of fire trenches and communication trenches per kilometre of front. This intensification can be explained both by the mobility of the front line ( $1^{\text {st }}$ and $2^{\text {nd }}$ battles of Champagne), and also by the strategic interest of this plain, which could accommodate large offensives. The Argonne region, with its forest environments, and the Vallage d'Aisne, with wet characteristics, were not appropriate sectors for attacks of great extent.

These defence networks (fire trenches and communication trenches) were organised in position, each consisting of several lines of trenches. In the Champagne sèche region, each camp had four positions. The Vallage d'Aisne and Argonne regions were better fortified by the French with five positions, while the Germans only had 
three and two respectively. The average area of the No Man's Land between the first lines of each army was similar in the Champagne sèche and in Argonne regions (158 $\mathrm{m}$ on average). The proximity of the two camps allowed for the development of the mine warfare (59 mine craters recorded in the Champagne sèche region and 91 in the Argonne region). Mine warfare, which is an ancient technique of breaking open the rampart of a fortress, was well suited to position warfare. The military engineering dug a gallery network of large sections towards the enemy, with subsequent narrower branches ending in explosive chambers called 'stoves', where concentrated black powder or explosives (melinite, cheddite) were placed. The necessary charge was calculated according to the nature of the soil (whose resistance associated with the coefficient $g$ was comparable to that of chalk and gaize, $g=2.25$ ) and the expected result (diameter of the mine crater). The 'mine systems' ranged from one explosion to more than 500, as in the case of the village of Vauquois. In our study area, this insidious war was possible only in the narrow No Man's Land - between 37 and 125 $\mathrm{m}$.

SSW-NNE geological cross-sections were constructed across French and German defence networks, using DTM, and marked by a red or blue initial for each trench intersected (Figure 5).

In the Champagne sèche region, the landscape was uncovered. The trenches were dug in chalk ridges, protected from enemy eyes, which did not allow a clear distinction of the different positions. French and German armies dug up to $16 \mathrm{~km} /$ $\mathrm{km}^{2}$ of fire trenches and communication trenches in the first $500 \mathrm{~m}$ of contact with the No Man's Land, or $160 \mathrm{~m} / \mathrm{ha}$. The first two positions of each camp were mixed up in the first $5 \mathrm{~km}$, both for fear of an enemy attack and to reinforce positions, but also as a consequence of the French attackers leading to retaking lost positions (two Champagne battles in 1915).

In the Vallage d'Aisne region, the three recovered positions of the French army were more widely spread out. This allowed more communication trenches in the defence and a lower trench density ( $74 \mathrm{~km} / \mathrm{km}$ front). The first position was established on the banks of Tourbes River (hydrographic barrier). The second and third were in promontory positions (observation sites) in marly chalk east of the Bionne River. On the other hand, the German army, located in the plain, established its three positions on the southern edge of the Ville, Cernay and Autry woods (vegetal mask effect).

In Argonne, under forest cover, the French army built four distinct positions, 4 to $5 \mathrm{~km}$ from each another. The first was adjacent to the No Man's Land on the right bank of the Biesme River, while the other three were located in promontory positions on the left bank of the Biesme River (second position), the Fontaine Le Prêtre brook (third position) and the Sougniat (fourth position) respectively. On the other hand, the German army built an extraordinarily dense first position, aligning up to 14 lines of fire trenches about 4 kilometres deep $\left(16 \mathrm{~km} / \mathrm{km}^{2}\right)$. A second discontinuous position was found at the top of the interfluve of the Bâtons River and the Charlevaux River $4.2 \mathrm{~km}$ from the No Man's Land area ${ }^{19}$. 


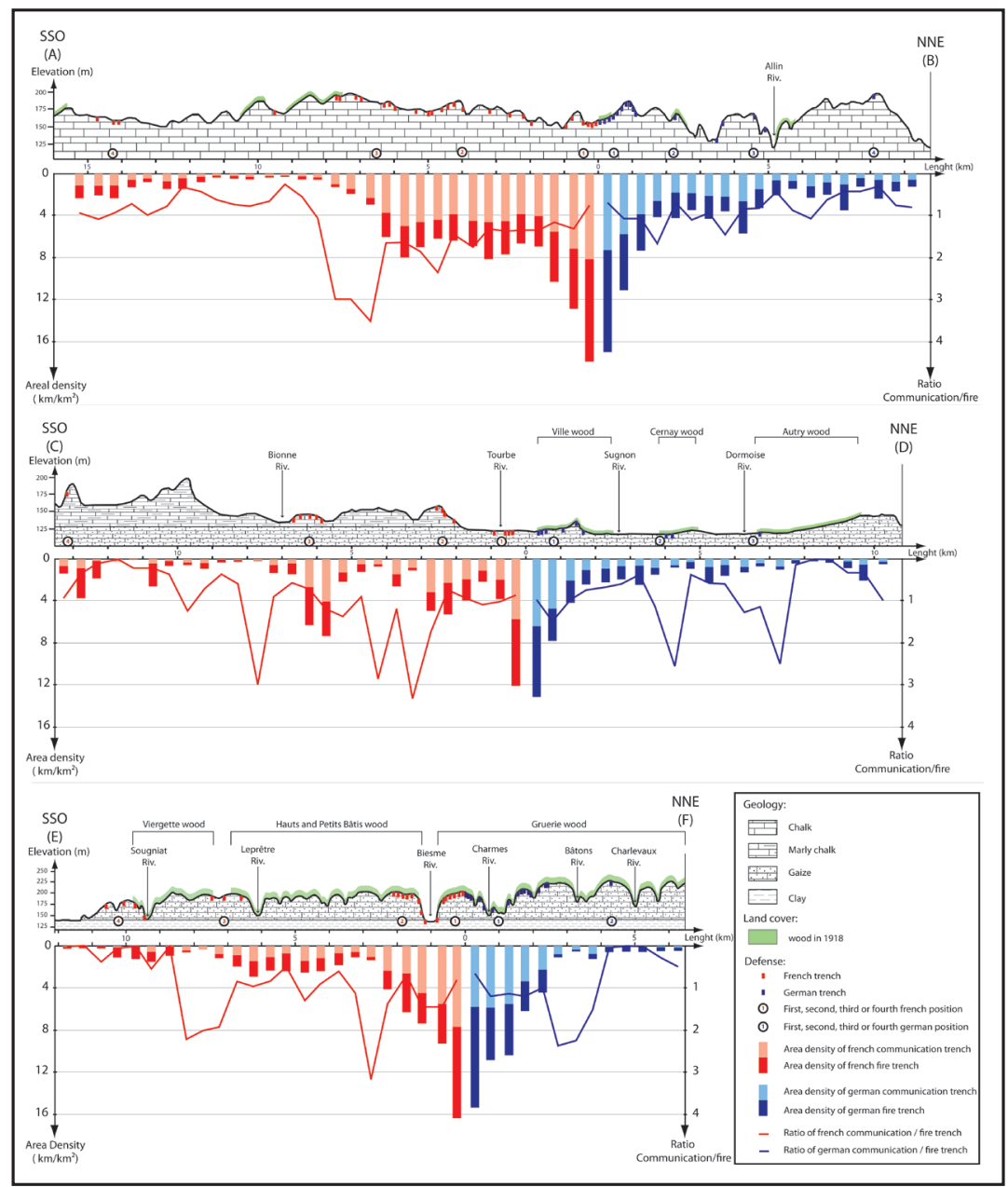

Figure 5: Cross-section of the defence network in the Champagne (A-B), the Vallage d'Aisne (C-D) and the Argonne regions (E-F) with area density of trenches and the ratio of the communication trenches and fire trenches.

The ratio of communication trenches to fire trenches was close to 1 in the intrapositions; therefore, with as many fire trenches as there were communication trenches (intra-position), whereas this ratio was 2 to 3 between the positions for the routing of the men and equipment (inter-positional communication trenches).

Therefore, the defence network was not spatially homogeneous because it was conditioned by the relief, nature of the terrain, hydrography and vegetation cover 
that determined sites of observation (topographic peaks), fire (military peaks), and covered or masked (forest, blind spot) areas. Ranges between positions were also related to the artillery range. In the Champagne sèche region without forest cover, the defence network was visible and spread out for protection from artillery impacts. It remained thick because it was fixed on chalk ridges, which constituted defence and observation sites. In the Vallage d'Aisne region, the hydromorphy limited the thickness of networks, and the flatness caused spreading out of the defence network. Finally, in the Argonne region, the forest cover smoothed the relief effect and guaranteed visual protection against artillery. It involved an intense densification of defence networks that crystallised in first position on ridges (mine warfare).

\section{Conclusion}

The contribution of spatial analysis of the trench maps of the Groupes de Canevas de Tir is innovative because it finally makes it possible to quantify this front area by morphometric indices (linearity, density, thickness). Too often represented as a line, the area was structured into positions comprising trench lines whose spatial organisation depended on the geomorphological, hydrographic and vegetation conditions, but also on the ballistic conditions (range of fire). The cleared plains (chalky Champagne) were conducive to large infantry attacks, while the hierarchisation of relief undeniably structured the curtains of defence. The front stretched out for almost $40 \mathrm{~km}$. In wetland (Vallage d'Aisne) and under forest in the Argonne plateau, the hydromorphy of the soil and the forest cover considerably smoothed the effect of the relief and constituted a major constraint for the progress of the troops. This resulted in a lower density of defence networks. The spatial analysis is therefore promising because it finally makes it possible to quantify by morphometric indices. This highlights the association between the war and geography.

Use of airborne $\mathrm{LiDAR}^{20}$ shows that landform conservation of defence networks is greatly influenced by landscape changes since 1919, with vegetation cover dependent on agricultural and forestry practices that have attenuated or even levelled them. In the Champagne sèche region, all of these 'polemo-forms' have been levelled for recultivation on chalky soils providing very good agricultural yield. However, 13,500 ha retained most of the impacts of this war because of the presence of the military camp of Suippes, which has become a real conservation area of the morphologies of the Great War. These forms are also best preserved in the woods and forest of the Vallage d'Aisne region and in the Argonne forest even though they have been affected by partial infilling over the last 100 years $^{21}$. In some forest areas, they have been fully filled after restocking and harvesting. In addition, there is the problem of their disappearance in the next centuries. Associations, such as Sommepy-Tahure, Cote 108, Main de Massiges and Vauquois are participating in and contributing to the memory and remembrance work by maintaining and enhancing these cultural heritage sites. 


\section{Acknowledgements:}

This contribution is part of the research programme Emergence - IMPACT 1418 backed by EA3795 - GEGENAA and funded by the Grand Est Region.

\section{Endnotes}

${ }^{1}$ F Cochet. Rémois en guerre 1914-1918: l’hérö̈sation au quotidian. Nancy: Presses universitaire de Nancy, 1993. F Cochet. La Grande Guerre, fin d'un monde, début d'un siècle. Paris: Perrin Press, 2014. G Alcaix. Du Chemin des Dames à la Marne. Louviers: Ysec Press, 2012.

${ }^{2}$ R Szymanski. Les Ardennes, terre de France oubliée en 1914-1918. CharlevilleMézières: Ardennais Press, 1984. A Bernède. Combats en Argonne 1914-1918. Saint-Cloud: Soteca Press, 2015. Y Desfossés. "Le camp de repos allemand du borrieswalde en forêt d'Argonne". Culture et Recherche 131. 2015. 15-16.

${ }^{3}$ Y Desfossés, A Jacques \& G Prilaux. L'archéologie de la Grande Guerre. Rennes: Ouest-France/INRAP Press, 2008.

${ }^{4}$ B Schnitzler, M Landolt, S Jacquemot, J-P Legendre \& J-C Laparra, eds. À l'Est, du nouveau! Archéologie de la Grande Guerre en Alsace et en Lorraine. Strasbourg: Strasbourg Museum Press, 2013. J Brénot, N Saulière, C Léty, P Taborelli, B Zélie, R Blondeau \& A Devos. "How much did the soldiers dig? A quantification of WW1 remains in Argonne, France". Geoarcheology 2017. 32/5. 534-548. doi: 10.1002/gea.21623. R Hesse. "Geomorphological traces of conflict in high-resolution elevation models". Applied Geography 46. 2014. 11-20. doi: 10.1016/j.apgeog.2013.10.004

${ }^{5}$ A Dubail \& M-E Fayolle. La guerre racontée par les généraux commandants de groupe d'armées, Vol 1: de liège à Verdun 1914-1916, Vol 2: de la Somme au Rhin 1916-1918. Paris: Schwarz Press, 1921. M Neiberg. Atlas de la première guerre mondiale. Paris: Histoire and Collections Press, 2015.

${ }^{6}$ J-P Hupy \& R Schaetzl. "Introducing 'bombturbation', a singular type of soil disturbance and mixing”. Soil Science 171/11. 2006. 823-836. doi: 10.1097/01. ss.0000228053.08087.19 and see also MS Rosenbaum \& EPF Rose. "Geology and military tunnels". Geology Today 8. 1992. 92-98.

${ }^{7}$ E Savouret, JP Amat, O Cantat \& P Filippucci. "Au temps météorologique de la Grande Guerre". Climatologie 8. 2011. 59-77. S Jacquemot, Y Prouillet \& F Steinbach. "Effacer les traces ou les conserver?" In Schnitzler et al. op cit., p. 336. Y Prouillet. "Un patrimoine convoité”. In Schnitzler et al. op cit., pp. 340-341.

${ }^{8}$ W Gheyle, R Dossche, J Bourgeois, B Stichelbaut \& V van Eetvelde. "Integrating archaeology and landscape analysis for the cultural heritage management of a World War I militarised landscape: The German field defences in Antwerp". Landscape Research 39/5. 2012. 502-522. doi: 10.1080/01426397.2012.754854. $\mathrm{R}$ Villate. Les conditions géographiques de la guerre, étude de géographie militaire sur le front français de 1914 à 1918. Paris: Payot Press, 1925. A Hertzog. "L'importance et l'influence de la géographie". In Schnitzler et al. op cit., pp. 33-34. 
${ }^{9}$ A Devos, P Taborelli, M Dodici, L Chalumeau, J Buridant, N Bollot, A Combaud \& Y Desfossés. "Rôle des conditions géographiques sur l'organisation spatiale des réseaux de défense de la Grande Guerre. Application à la Champagne (région de Reims)". Physio-Géo 9. 2015. 157-174. doi: 10.40000/physio-geo.4615

${ }^{10}$ B Stichelbaut. "The first thirty kilometers of the western front 1914-1918: An aerial archeological approach with historical remote sensing data". Archeological Prospection 18/1. 2011. 57-66. doi: 10.1002/arp.397

${ }^{11}$ A Combaud, A Devos, L Chalumeau, P Taborelli \& N Bollot. "Les Plans directeurs de la Grande Guerre: une nécessaire innovation cartographique". Revue internationale de Géomatique 3. 2016. 363-393. doi: 10.3166/rig.2016.00004. P Taborelli, A Devos, M Dodici, N Bollot, Y Desfossés \& J Brenot. “Apport des plans directeurs sur la compréhension de l'organisation spatiale du front durant la grande Guerre Application à L'Argonne". Revue de géographie historique 8. 2016. <http://rgh.univlorraine.fr/articles/view/66/Apport des plans_directeurs_sur_la_comprehension_de _ 1_organisation_spatiale_du front durant la Grande Guerre Application a 1 Argonne $>$ Accessed on 15 December 2017.

${ }^{12} \mathrm{P}$ Taborelli, A Devos, S Laratte, J Brenot, N Bollot, B Cancès \& Y Desfossés. "Apport des plans directeurs et de l'outil LiDAR aéroporté pour la caractérisation des impacts morphologiques de la Grande Guerre - Exemple de la Cote 108 (Berry-au-Bac - France)". Géomorphologie, relief, processus, environnement 23/2. 2017. 155-169.

${ }^{13} \mathrm{H}$ Guérin \& M Laurain. "Itinéraire géologiques et géomorphologiques en Argonne". Annales scientifiques de l'université de Reims et de l'A.R.E.R.S 18. 1982. 25-36.

${ }^{14} \mathrm{~J}$ Léry. La bataille dans la forêt (Argonne 1915), Impression d'un témoin. Paris: Hachette Press, 1916.

${ }^{15}$ J Laurent. "L'Argonne et ses bordures". PhD thesis, University of Paris, 1948.

${ }^{16} \mathrm{P}$ Boulanger. "La carte d'Etat-Major au service de la géographie militaire (début XIXe siècle - 1939)”. Stratégique 82/83, vol. 2-3, 2001. Institut de Stratégie Comparée (ISC). Accessed online on 15 December 2017 http://www.institutstrategie.fr/Strat8283-10.htm

${ }^{17}$ Grand Quartier Général Des Armées - État-Major. Instruction sur les plans directeurs. Paris: National Printing House, 1916.

${ }^{18}$ ibid

${ }^{19} \mathrm{R}$ Porte. "L'état-major allemand aurait fait imprimer 800 millions de cartes!" IGN Magazine 74. 2014.

${ }^{20}$ P Taborelli, A Devos, S Laratte, N Bollot \& J Brénot. “Typologie et organisation spatiale des «polémo-formes » de la Grande Guerre révélées par l'outil LiDAR et les Plans Directeurs. Application à la Champagne et à l'Argonne". Revue de Géographie Historique 10. 2017. <http://rgh.univlorraine.fr/articles/ view/88/Typologie et organisation spatiale des polemo formes de la Grande_Guerre_revelees_par_1_outil_LiDAR_et_les_Plans_directeurs Application a la Champagne et a 1 Argonne $>$ Accessed on 15 December 2017.

${ }^{21}$ ibid 